УДК $82-1$

\title{
С.В. Гречишкина
}

\section{РАЗВИТИЕ ПОЭЗИИ О ПРИРОДЕ В США: СТАНОВЛЕНИЕ ЭКОПОЭЗИИ}

\begin{abstract}
Статья посвящена американской поэзии о природе. Цель исследования - выявить этапы развития поэзии о природе, уделив особое внимание такому феномену, как экопоэзия. Одной из основных задач является раскрытие отличительных черт данного вида поэзии. Важной задачей также является выяснение того, какие ценности легли в основу образа природы на каждом из этапов. Основными методами исследования выступают культурно-исторический метод и метод сравнительного анализа. Ведущим подходом исследования избран аксиологический. Материалом исследования служат произведения известных американских поэтов от периода колонизации до наших дней.

Ключевые слова: американская поэзия; поэзия о природе; образ природы; эколитература; экопоэзия; ценности.
\end{abstract}

В российском литературоведении существует достаточное количество работ, посвящённых американской литературе в целом и поэзии в частности. Автор статьи обращается к трудам таких известных российских и зарубежных исследователей американской поэзии, как А. Генис, В. Гандельсман, Б.А. Гиленсон, А. Грицман, Р. Грэй, А. ДиФранко, С.Д. Павлычко и Е.А. Стеценко. Данное исследование актуально в силу увеличения интереса к произведениям о природе, к ценностям, которые транслируются литературой. Автор статьи исходит из утверждения, что отличительные черты образа природы зависят от ценностной модели мира поэта и эпохи в целом. Профессор И.И. Докучаев уверен, что за каждым художественным образом стоит характерная для автора ценностная модель реальности, поскольку при создании художественного образа автор отбирает её определённые смысловые компоненты [1. С. 142-144]. Известно, что «каждая новая ступень в развитии человечества создаёт свою систему ценностей, наиболее адекватно соответствующую условиям её существования» [2. С. 34]. Важной задачей исследования является выявление ценностей, лежащих в основе создания образа природы в тот или иной период развития поэзии о природе, а также обусловивших появление такого феномена, как экопоэзия. Основное внимание в работе сосредоточено на идейно-художественных особенностях произведений различных периодов.

Новизна работы заключается в выявлении периодов развития поэзии о природе, в обращении к малоисследованному в российском литературоведении феномену экопоэзии, возникшему на последнем этапе развития поэзии о природе, а также в избранном подходе к изучаемому материалу. Предметом анализа становятся стихотворения таких поэтов, как А. Брэдстрит, Ф. Френо, Т. Дуайт, У.К. Брайант, Р.У. Эмерсон, Э. Дикинсон, Г.Д. Торо, У. Уитмен, Г.У. Лонгфелло, Г. Мелвилл, Т.С. Элиот, У.К. Уильямс, Р. Фрост, Э. Бишоп, М. Оливер, Г. Снайдер, Ш. Алекси, а также Дж. Харджо.

Известно, что ещё до прихода колонистов существовало устное творчество коренных народов в таких формах, как песни, напевы, молитвы, рассказы и стихи. Культура коренного населения была основана на тесной взаимосвязи с природным миром: произведения индейцев демонстрировали особую духовную связь с местом проживания и представителями животного мира [3. С. 219]. Б. Гиленсон указывает, что индейцы выработали систему художественных ценностей, основанных на гармонии с природой, понятиях справедливости и равенства [4. С. 21]. Человек для индейцев - член природного сообщества. С приходом колонистов в произведениях индейцев зазвучал трагизм, ознаменовавший осознание ослабления связей со всем природным миром, что отчасти явилось результатом переселения с привычных мест проживания [3. C. 220].

Несмотря на то что ещё до прихода колонистов были созданы разнообразные произведения, существует мнение, что американская поэзия возникла в XIX в. [5. С. 1]. Как самостоятельное языковое и культурное явление американская поэзия, по мнению А. Грицмана, сформировалась с появлением Эмерсона и По. Он утверждает, что именно в эпоху романтизма ощущение неосвоенного пространства континента сыграло ключевую роль в рождении американской поэзии [6]. Природа континента стала источником национальной литературы, а тема природы - центральной для творчества многих поэтов. В данном исследовании во внимание берутся среди прочего произведения, созданные до XIX в. Необходимо сначала обратиться к периоду колонизации.

Если индейцы считали, что человек - равноправный член природного сообщества, то колонисты были уверены, что природа подчинена человеку, поскольку бог создал её в угоду человеку. На первом этапе отношение к природе обусловливалось идеями пуританизма. Мысль о греховном падении человека является центральной для литературы времён начала колонизации, предназначение которой виделось в прославлении бога и утверждении веры. Примером могут служить произведения Анны Брэдстрит (1612-1672), в основном написанные рифмованным ямбом, которая, по замечанию Б.А. Гиленсона, стоит у истоков американской поэзии [4. С. 23]. Согласно Брэдстрит, красота природы - это проявление красоты создателя, поскольку именно бог создал природу. Например, в стихотворении «Созерцание» (Contemplations) Брэдстрит задумывается о том, насколько прекрасен создатель, если прекрасна созданная им природа:

If so much excellence abide below,

How excellent is he that dwells on high?

Whose power and beauty by his works we know [7].

Пространство в стихотворениях Брэдстрит обычно имеет чёткое разделение на «верх» и «низ». «Верх» 
(небеса) наделяется Брэдстрит положительными качествами, а «низ» (земля) - отрицательными. В образе природы, однако, выражено восхищение красотой, усиленное метрической упорядоченностью стиха (Брэдстрит придерживается характерного для того времени пятистопного ямба), и одновременное осознание греха, не дающее насладиться красотой природы сполна:

Thy pleasing fervour, and thy scorching force,

All mortals here the feeling knowledge hath.

$<\ldots>$

When present times look back to Ages past

And men in being fancy those are dead... [7].

Сдержанность отклика красотам природы обусловлена, как уже было отмечено, принадлежностью к пуританизму. Брэдстрит на вопрос, стоит ли восхвалять деревья и землю, даёт себе отрицательный ответ, подчёркнутый использованием ряда слов с отрицательной коннотацией:

Nay, they shall darken, perish, fade and dye,

And when unmade, so ever shall they lye... [Ibid.].

Несмотря на то что тема служения Богу является центральной в её стихотворениях, темы природы и семьи становятся также их неотъемлемой частью. В целом стихи Брэдстрит, посвящённые детям, мужу, домашним делам, говорят о её привязанности к земной жизни.

Природные образы Брэдстрит частично заимствует из Библии. В стихотворении «О её детях» (In Reference to her Children) Брэдстрит, например, сравнивает своих детей с птенцами [8]. В тех стихотворениях, где природные образы не заимствованы из Библии, Брэдстрит использует приём олицетворения, и природа обретает антропоморфные качества. Например, этот приём можно найти в следующем отрывке из стихотворения «Созерцание»:

When I behold the heavens as in their prime,

And then the earth, though old, still clad in green,

The stones and trees insensible of time,

Nor age nor wrinkle on their front are seen [9. P. 2].

Профессор А. ДиФранко отмечает, что не только стихи Брэдстрит, но и вся литература колонистов подчинена единой теме служения Богу, а образы природы используются в произведениях для выражения Его величия [3. С. 221]. Лишь со временем акценты начинают меняться: идея греховности постепенно уходит, поэзия становится более секулярной. Подтверждением является поэзия Филипа Френо (17521832). По утверждению Б. Гиленсона, Френо хорошо известен как автор пейзажной, медитативной лирики [4. С. 39]. Среди самых известных стихотворений Френо о природе выделяются «Вскармливание диким мёдом» (The Wild Honey-Suckle) и «Религия природы» (On the Religion of Nature), поэма «Дом ночи» (The House of Night) [Там же]. В стихотворении «Религия природы» природа представлена дающим, неагрессивным (smiling land) началом. Природа у Френо - это созидающее, женское начало (creatress nature), образ которого создаётся за счёт богатой аллитерации и рифмы:

To whom creating Nature gave

Ten thousand streams to swell thy sway! [9. P. 10].
Роль созидания, таким образом, присуща, по мнению Френо, не только Богу. В произведениях Френо представлен распространённый образ природыматери, характерный для произведений многих народов мира.

Френо проявлял живой интерес к культуре индейцев, их традициям и их особой связи с природой. Данный интерес нашёл отражение в таких стихотворениях, как «Индейское кладбище» (Indian Graveyard) и «Место захоронения индейцев» (The Indian Burying Ground), в которых образ природы непосредственно связан с образом индейца. Френо, подчёркивая особую связь индейцев с природой, называет их «детьми леса»:

Here still an aged elm aspires,

Beneath whose far-projecting shade

$<\ldots>$

The children of the forest played! [10].

В произведениях Тимоти Дуайта (1752-1817), ещё одного американского поэта, чьё творчество можно отнести к первому периоду развития поэзии о природе, можно найти своеобразный топос, общее место, в американской литературе: связь образа природы с образом страны. Образ природы служит выражению идеи величия страны. Например, в произведении «Холм Гринфилд» (Greenfield Hill) Дуайт прославляет Америку, говоря о возвышающихся к небесам горах и бесчисленных фермах:

Beyond, a little chasm to view unfolds

Cerulean mountains, verging high on HEAVEN,

In misty grandeur. Stretch'd in nearer view,

Unnumber'd farms salute the cheerful eye... [11].

Френо и Дуайт с помощью образа природы пытаются передать идею национального превосходства американцев, которое, по их мнению, является в первую очередь следствием лучших природных условий. Образ природы Америки - это образ благословенной земли, создаваемый за счёт употребления большого количества восхваляющих эпитетов:

A happier soil, a milder sway,

Where no proud despot holds him down,

No slaves insult him with a crown.

$<\ldots>$

And happier systems bring to view,

Than all the eastern sages knew. [9. Р. 10-11].

Несмотря на то что поэзия о природе постепенно становилась более секулярной, тема природы в поэзии Френо, а также в поэзии Дуайта неразрывно связана с темой религии. В некоторых стихотворениях есть противопоставление жизни земной и жизни в раю. Например, Френо в стихотворении «Вскармливание диким мёдом» описывает увядание цветов, земная жизнь которых более быстротечна, как и жизнь человека, в сравнении с жизнью в раю [Ibid. Р. 15]. Выражена идея превосходства жизни в раю.

Значительные изменения образ природы претерпевает в эпоху романтизма, ознаменовавшей начало нового этапа в развитии поэзии о природе. Именно в эту эпоху многие поэты осознают благотворное влияние природы на человека. Переходу к такому представлению о природе во многом способствовало творчество Уильяма Каллена Брайанта (1794-1878), которого 
называют «зачинателем романтической поэзии в США» [4. С. 47]. В известном стихотворении «Танатопсис» (Thanatopsis) он характеризует природу как «целительный бальзам», предупреждающий «сознанье боли» [Там же].

В поэзии о природе эпохи романтизма становится менее выражена идея связи природы с Богомсоздателем. Например, стихотворение «Прерии» (The Prairies) Брайанта отличается более секулярным, чем у предшествующих поэтов, видением природы. Брайант отходит от понимания природы как греховного мира, в его произведениях чувствуется внимательное отношение к пейзажам Иллинойса [3. С. 225]. Однако Брайант всё-таки признаёт природу созданием Бога. В стихотворении «Лесной гимн» (A Forest Hymn), например, он называет рощи храмом Божьим, а в конце говорит, что люди должны следовать установленному Богом порядку в природе:

And to the beautiful order of the works

Learn to conform the order of our lives [12. P. 74].

Однако не воспевание Бога - главная цель стихотворений Брайанта о природе, главная цель - доказательство положительного воздействия природы на человека. Желание подчеркнуть красоту природы и природных созданий лежит в основе написания одного из самых известных произведений Брайанта «К водоплавающей птице» (To a Waterfowl). В этом стихотворении Брайант умело варьирует длину строк в каждой строфе для передачи движение птицы в полёте [Ibid. P. 74-76]. Данный приём - пример поиска поэтами эпохи романтизма новых форм выражения. Вместо классического для английского стихосложения рифмованного ямба некоторые поэты начинают экспериментировать с белым стихом (Эмерсон, Торо). Такие эксперименты лишь подчёркивают новизну содержания произведений данной эпохи.

Не только Брайант отмечает целительную, обновляющую силу природы. Поэт Уильям Гилмор Симмс (1806-1870), например, в стихотворении «Полёт к природе» (Flight to Nature) также отмечает это свойство:

Sweet Nature, how I turn to thee,

Seeking for renovated life [13].

Несмотря на признание целительного свойства природы, она, по мнению поэта, подчинена человеку. Основной ценностью второго периода является ценность человеческой индивидуальности. Природа же, по мнению авторов, призвана удовлетворять разнообразные потребности человека, в том числе потребность в получении эстетического удовольствия. Не случайно образ природы у Брайанта - это образ дома человека, созданного Богом («Лесной гимн»), хотя этот «дом» напоминает живое существо, реагирующее на внутренние и внешние изменения:

Nay, doubt we not that under the rough rind,

In the green veins of these fair growths of earth,

There dwells a nature that receives delight

From all the gentle processes of life,

And shrinks from loss of being. Dim and faint...

[9. P. 25]

В эпоху романтизма поэты задумываются о возможной угрозе, которую несёт человек природе своей деятельностью. Брайант в одном из стихотворений представляет срубаемое дерево как существо, обладающее чувствами, что заставляет читателя задуматься над тем, чья жизнь (жизнь человека или жизнь дерева) обладает большей ценностью:

$<\ldots>$ Do there not run

Strange shudderings through your fibres when the axe Is raised against you, and the shining blade

Deals blow on blow, until, with all their boughs,

Your summits waver and ye fall to earth? [9. P. 5].

В творчестве Брайанта нашли выражение две разнонаправленные черты. С одной стороны, образ природы связан с образом родных для писателя мест:

Or lose thyself in the continuous woods

Where rolls the Oregon, and hears no sound [Ibid.].

С другой стороны, образ природы связан с образом страны и нации в целом. От Брайанта прозвучал самый ранний призыв к созданию национальной американской литературы, которая, по его мнению, могла возникнуть благодаря прекрасным природным условиям на континенте [3. С. 224]. Идея о превосходстве природы американского континента над европейской природой, а также идея об определении характера человека природой выражена в стихотворении Брайанта «Сонет американскому художнику, уезжающему в Европу» (Sonnet - To an American Painter Departing for Europe) [9. Р. 27].

О важности национальной литературы, которая будет способствовать распространению моральных и культурных идеалов, а также формированию американского характера в 1830 г., заявлял американский писатель У.Э. Чаннинг [14. С. 69]. Вслед за Чаннингом мощный призыв к созданию национальной литературы прозвучал от Р.У. Эмерсона (1803-1882) в ряде его лекций и эссе. Считая, что в Америке пока не появилось гения, способного выразить национальную специфику, Эмерсон заявил, что Америка - это стих, который вскоре должен получить метрическое выражение. Эмерсон считал, что именно природа может вдохновить национального поэта [15. С. 737].

Именно с деятельностью Эмерсона и деятельности кружка трансценденталистов во главе с ним связаны основные изменения в образе природы. В диссертации «Философская поэзия американского романтизма (поэтическое творчество Ралфа Уолдо Эмерсона и Эмили Дикинсон)» С.Д. Павлычко указывает, что для Эмерсона характерно романтическое понимание природы как сущности, независимой от цивилизации и культуры, как некоего откровения [16. С. 27]. Эмерсон способствовал проникновению в США идей европейского романтизма (1820-1865) [17]. Он перенял идеи Вордсворта и Кольриджа, которые являлись одними из ключевых фигур литературы Великобритании эпохи романтизма [18. С. 116]. Профессор К. ВанСпанкерен также утверждает, что многие идеи Эмерсона берут свое начало из буддизма, ислама и учения Конфуция [19]. Эмерсон соединил все эти источники с идеями немецкого идеализма, восточной философией и сформулировал постулаты американского трансцендентализма, литературно-философского течения, уделявшего основное внимание идее одухотворённости природы. Трансценденталисты верили в то, что человек может нравственно очиститься, приблизившись к природе. 
Трансцендентализм США сохраняет в себе такие особенности эпохи романтизма, как противостояние рационализму, внимание к личности человека, идею об особом предназначении поэта и, конечно, идею о необходимости преклонения перед природой, в которой, по мнению приверженцев трансцендентализма, присутствует божественный дух [20]. В творчестве трансценденталистов активно развивается идея пантеизма. Эмерсон, убеждённый в слитности бога с природой, одним из первых выражает идею ценности природы как источника эстетического наслаждения:

Tell them, dear, that if eyes were made for seeing,

Then Beauty is its own excuse for being [9. Р. 32].

В стихотворениях о природе Эмерсон поднимает проблемы философского характера. В философской лирике Эмерсона зарождается космическое видение мира [16. С. 33]. Найти этому подтверждение можно в стихотворении «Все и каждый» (Each and All) [21]. Важным открытием Эмерсона является также его идея природы как чего-то изменяющегося: «То, что мы называем природой, на самом деле является саморегулирующимся движением, изменением: природа всё делает сама» [15. С. 731]. Природа у Эмерсона это активная, саморегулирующаяся сущность, способная на ответные действия.

В творчестве Эмерсона, как и в творчестве Брайанта, выражена идея воздействия человека на природу, в том числе негативного воздействия. Однако это воздействие, по мнению Эмерсона, не одностороннее. В стихотворении «Вода» (Water), например, говоря о взаимосвязи природы с человеком, он пишет, что природа способна на разрушительные действия в ответ на неподобающие действия человека:

Ill used, it will destroy [9. P. 30].

Хотя можно заметить, что стихотворения Эмерсона всё-таки чаще оптимистичны:

The water understands

Civilization well;

$<\ldots>$

Well used, it decketh joy,

Adorneth, doubleth joy [Ibid.].

Признавая прочную взаимосвязь между человеком и природой, Эмерсон высказывает мысль о нетождественности человека природе: we are strangers to the stars, / And strangers to the mystic beast and bird, / And strangers to the plant and to the mine [Ibid. P. 31]. Heсмотря на это, в произведениях Эмерсона прослеживаются зачатки экопоэзии: в них уделяется внимание взаимоотношению различных природных элементов. Например, в стихотворении Эмерсона «Басня» (Fable), в котором разворачивается диалог белки с горой. Таким образом, используя аллегорию, Эмерсон признаёт равнозначную необходимость каждого природного элемента:

Talents differ; all is well and wisely put;

If I cannot carry forests on my back,

Neither can you crack a nut [Ibid. P. 34].

Даже «неживая» природа обретает в стихотворениях Эмерсона голос. Голосом обладает природа и в стихотворениях Кэролин Таппан (1818-1888), другого члена кружка трансценденталистов. Она персонифицирует природу и использует приём психологическо- го параллелизма, приписывая природе чувства, которые соответствуют внутреннему настроению лирического героя. В стихотворении «Лирика» (Lyric) она пишет:

The little flowers lie low on the ground

And sadly moan [21].

В стихотворении «Строки» (Lines), посвящённом решению вопроса о сущности природы, природа представлена как прекрасная мать:

No! the secret of Nature I do not know -

A poor groping child, through her marvels I go! [Ibid.].

Известно, что образы природы в эпоху романтизма часто служили символами. Например, подсолнух в стихотворении английского поэта У. Блейка «Ах, подсолнух» (Ah! Sun-flower) символизирует желание достичь вечной жизни, змея в произведении С.Т. Кольриджа «Кристабель» (Christabel) - зло, а чёрный ворон в стихотворении Э. По «Ворон» (The Raven) - смерть.

Отчасти использование символов в эту эпоху связано с изменением статуса поэта. В США он резко поднимается, во многом благодаря Эмерсону. В своём эссе «Поэт» (The Poet) он объясняет, что настоящий поэт «видит то, о чем другие лишь мечтают, и подчиняет это себе, и пропускает сквозь себя все многообразие опыта; он - представитель рода человеческого благодаря тому, что в нём всего больше развиты способности воспринимать и передавать другим» [22. С. 304]. По мнению Эмерсона, поэт должен обладать особой способностью восприятия и выполнять важные социальные функции по передаче знания, полученного при восприятии. Для этого он может использовать символы.

Необходимо упомянуть Генри Дэвид Торо (18171862), также входившего в кружок трансценденталистов. Он является одним из самых выдающихся мыслителей, повлиявших на восприятие природы американцами. К. ВанСпанкерен пишет, что мысли Торо об экологии, его идеи, наблюдательность до сих пор актуальны и свежи [19]. Конечно, большая часть внимания исследователей к творчеству Торо сосредоточена на эссеистике и журнале, в котором Торо делал записи о результатах наблюдения за природой. Однако Торо является также автором стихотворений.

В стихотворениях Торо происходят своеобразная интериоризация и в то же время персонификация природы. Например, в произведении «Внутреннее утро» (The Inward Morning) он пишет:

Packed in my mind lie all the clothes

Which outward nature wears [21].

Торо, как и Эмерсон, увлекавшийся восточной философией, сочетает в своих произведениях идеи немецкого идеализма с идеями индийской философии, в том числе с идеей о брахмане и атмане, т.е. о едином божественном начале природы и человека. Торо, как и Эмерсон, является последователем пантеизма и считает, что природа слитна с божественным началом. В «Молитве Земле» (Pray to What Earth) он говорит о необходимости молиться земле [Ibid.].

Итак, в творчестве поэтов-трансценденталистов заметны важные изменения в образе природы: природа наделяется божественными качествами, утвержда- 
ется единое начало человека и природы, исчезает пространственная дихотомия «верх-низ», реализующая разницу между положительным, божественным, находящимся вверху, и отрицательным, греховным, находящимся внизу.

Говоря о новаторстве, необходимо упомянуть Уолта Уитмена (1819-1892), поэта, положившего начало по-настоящему национальной американской поэзии. Он представляет собой того поэта, появление которого предсказывал Эмерсон в эссе «Поэт». Не случайно сам Эмерсон признал Уитмена самобытным поэтом [4. С. 128]. Уитмену удалось совершить революцию в стихосложении, а также выразить демократические настроения страны. Уитмен использует длинные строки для выражения идеи безграничности просторов и возможностей, которые можно найти в Америке. «Листья травы», основное произведение Уитмена, написано свободным стихом для выражения идеи свободы от каких-либо ограничений:

Walt Whitman, an American, one of the roughs, a kosmos,

$<\ldots>$

I speak the password primeval... I give the sign of democracy;

By God! I will accept nothing which all cannot have their counterpart on the same terms [9. P. 102].

Хотя при написании «Листьев травы» Уитмен использовал множество источников (итальянскую оперу, перевод Библии, выполненный под руководством короля Якова I, астрономию, ландшафтную живопись и проч.), основным источником для него стало ощущение значимости своей личности, идентификация себя со своей родиной [18. С. 208]. Таким образом, в основе создания образа природы в его творчестве заложена одна из ведущих ценностей американской культуры - ценность человеческой личности.

Своё личное «я» Уитмен ставит превыше всего. В творчестве Уитмена и многих поэтов, живших после него, наблюдается желание поделиться с читателем своим опытом, личными соображениями. Р. Грэй указывает на то, что фокус произведения на личностном «я» повествователя или автора, как собственно соединение, слияние повествователя и автора, для американской литературы является типичным [23. С. 123]. В произведении Уитмена «Листья травы» образ природы - это, в первую очередь, образ страны, в которой человек свободен.

Как уже было отмечено ранее, произведения Эмерсона были оптимистичными. Идею оптимизма, представленного Эмерсоном в эссе «Доверие к себе» (Self-Reliance) как необходимое качество человека, выражает и Уитмен. Он пишет:

The earth good, and the stars good, and their adjuncts all good [9. Р. 89].

В произведении Уитмена можно найти общий для английской и американской поэзии топос эпохи романтизма: образ природы как учителя (данный образ можно найти у Вордстворта, в стихотворении «Природа-учитель» (The Tables Turned)). Уитмен считает, что природа может научить большему, чем проповедь или лекция:
Logic and sermons never convince,

The damp of the night drives deeper into my soul

[9. P. 107].

Однако Уитмен далёк от признания единства человека с животными, которое свойственно творчеству индейцев. Он отделяет животных от рода человеческого:

I think I could turn and live awhile with the animals.... They are so placid and self-contained,

$<\ldots>$

So they show their relations to me and I accept them [Ibid. P. 108].

Новым в поэзии Уитмена является его идея многозначности природных образов. Например, трава, имея зелёный цвет, может означать надежду, может восприниматься как проявление божественного начала, может означать рождение, поскольку постоянно прорастает вновь, а может символизировать смерть, поскольку растёт на могилах. Тот факт, что трава растёт везде, даёт право говорить, что она означает также единство [Ibid. P. 88]. Именно единство всего сущего утверждает Уитмен в своём основном произведении «Листья травы»:

What is a man anyhow? What am I? and what are you?

All I mark as my own you shall offset it with your own,

Else it were time lost listening to me [Ibid. P. 98].

Большое влияние на развитие поэзии о природе оказало творчество Эмили Дикинсон (1830-1886), задававшейся вопросом о сущности человека. Она, как и Уитмен, была склонна определять сущность человека через природное начало. Пристальное наблюдение за природным миром позволило Дикинсон умело использовать сравнения животных с людьми и людей с животными. Например, в стихотворении «Я никто, а ты - ты кто?» (I'm Nobody! Who are you?) Дикинсон сравнивает человека с лягушкой:

How dreary - to be - Somebody!

How public - like a Frog -

To tell one's name - the livelong June -

To an admiring Bog! [24].

Данное стихотворение хорошо выражает жизненную позицию Дикинсон. В отличие от Уитмена Дикинсон всей своей жизнью затворника и своим нежеланием публиковать собственные произведения показывает, что ей чужды публичная жизнь и желание славы. Различия между двумя поэтами видны и в форме произведений. Строфы у Дикинсон короткие. Если Уитмен опирается на перевод Библии в выработке своего стиля, то Дикинсон - на церковные гимны [25. С. 83]. Дикинсон использует эллиптичные предложения, пытаясь высказать мысль минимальным количеством языковых единиц, что соответствует её идее о простоте природы. Самым любимым знаком препинания Дикинсон является тире. Этот знак не только передаёт быстрое движение мысли, но и служит созданию определённого ритма, получаемого также за счёт чередования строк с чётным и нечётным количеством ударных слогов и за счёт анжамбемана.

Образ природы у Дикинсон всеобъемлющ, как и у Уитмена, но создаётся он по-другому. Если Уитмен идёт 
от своего «я» вовне, то Дикинсон от внешнего мира к собственному «я», которое для неё является неотъемлемой частью природы. Дикинсон осознаёт тесную взаимосвязь всех живых существ, её интересует каждая мелкая деталь. Например, в стихотворении «Спорхнула птичка» (A Bird Came Down) она рассказывает о своём опыте наблюдения за птицей, поедающей червя.

Стихотворения Дикинсон лишены избыточной символичности, она повествует о своём непосредственном опыте общения с природой. Например, стихотворение «Маленькое существо в траве» (A Narrow Fellow in the Grass) лишено понимания змеи как символа зла. С точки зрения Дикинсон, всё в природе является гармоничным. В отличие от Эмерсона и Уитмена, однако, она считает, что выразить мудрость природы человеку не под силу. Например, в стихотворении «Природа - это то, что видим» (Nature” Is What We See) Дикинсон пишет:

Nay - Nature is Harmony -

Nature is what we know -

Yet have no art to say -

So impotent Our Wisdom is

To her Simplicity [26].

Образ природы у Дикинсон - это образ гармоничного целого. Он часто строится как образ друга. Например, в стихотворении «Марту» (To March) месяц март предстаёт в виде долгожданного гостя и друга.

Значительное место в истории развития поэзии о природе занимает творчество Генри Лонгфелло (1807-1882), получившего признание ещё при жизни. Популярность произведений Лонгфелло объясняется отчасти его приверженностью к традиционным европейским литературным формам [23. С. 203]. Образ природы США у Лонгфелло, задавшегося целью создать национальное эпическое произведение, связан с образом индейца. Гиленсон отмечает, что для романтической литературы характерно обращение к образу индейца как «естественного человека», однако, как правило, этот образ носит условный, декоративный характер. Лонгфелло, по словам Гиленсона, значительно глубже подходит к культуре индейцев в процессе создания своих эпических произведений [4. С. 84].

В его стихотворении «Природа» (Nature) образ природы - это также образ ласковой матери, заботящейся о своих детях - людях:

As a fond mother, when the day is o'er,

Leads by the hand her little child to bed,

$<\ldots>$

Being too full of sleep to understand

How far the unknown transcends the what we know [27].

Признавая, подобно Дикинсон, тот факт, что наше знание об окружающем нас мире слишком мало, Лонгфелло говорит, что человечество представляется скорее невинным дитя, чем грешным созданием. Его творчество соответствует второму этапу развития поэзии о природе, на котором на природу перестаёт проецироваться идея греховности. Однако не все американские поэты эпохи романтизма являются оптимистами и считают земную жизнь непосредственным контактом с божественным началом, растворённым в природе. Противоположный взгляд, например, характерен для Германа Мелвилла.
Г. Мелвилл (1819-1891) является не только автором знаменитого романа «Моби Дик», но и автором нескольких рассказов и стихотворений. В стихотворениях Мелвилла чувствуются мрачность, постоянное ощущение исходящей от природы опасности, как и в его известном романе. В стихотворении «Мальдивская акула» (The Maldive Shark), повествующем о симбиозе рыбы-лоцмана и акулы, акула предстаёт неким исчадием ада, для которого рыба-лоцман является прислужником, приводящим хозяина к добыче:

But liquidly glide on his ghastly flank

Or before his Gorgonian head;

Or lurk in the port of serrated teeth

In white triple tiers of glittering gates [9. Р. 155].

Можно сделать вывод, что Мелвилл, черпая символы из природного мира, хочет донести до нас мысль о единстве сущего, но единстве другого рода, чем у Уитмена. Мир, по мнению Мелвилла, похож скорее на ад, чем на рай. Если стихи Эмерсона и Уитмена проникнуты жизнеутверждающим оптимизмом, то стихи Мелвилла пессимистичны.

Пессимизм чувствуется даже в тех стихотворениях, в которых образ природы связан с образом страны. Например, в стихотворении «Опасения» (Misgivings) Мелвилл пишет:

When ocean-clouds over inland hills

Sweep storming in late autumn brown,

$<\ldots>$

I muse upon my country's ills [Ibid. P. 153].

Мелвилл не разделяет уверенность Эмерсона, Торо и других поэтов в особой судьбе страны, обусловленной прекрасными природными условиями.

Во многом трагичное мироощущение присуще следующему этапу развития литературы о природе в США. Данное мироощущение явился результатом Гражданской, а также Первой мировой войны. Если романтизм был эпохой оптимизма и надежд, то модернизм - разрушением этих надежд. Новое мироощущение было также результатом стремительных изменений в бытовом плане: увеличилось городское население, возросла скорость коммуникации (распространение получили радио и телефонная связь), выросла скорость транспортировки (строились мосты, метро, машины и скоростные поезда), возводились небоскрёбы, фабрики [28. С. 23].

Именно новое мироощущение заставляет модернистов ставить под сомнение жизнеспособность старых форм. Они начинают использовать новые формы произведений. Томас Стернз Элиот (1888-1965), например, в «Бесплодной земле» (The Waste Land) передаёт идею о нарушенной взаимосвязи человека с природой, дробя произведение на, казалось бы, не связанные между собой части. В произведении представлена мрачная картина послевоенного общества, которая создаётся с помощью природных образов, например образа загрязнённой Темзы:

Unreal City,

Under the brown fog of a winter dawn,

A crowd flowed over London Bridge, so many,

I had not thought death had undone so many [9. P. 353].

Образ природы - это образ собранных фрагментов, кусков, между которыми нет видимой связи. Однако, 
как указывает А. ДиФранко, в основе произведения Элиота лежит традиция сезонных ритуалов плодородия [3. С. 228]. Несвязность произведения только кажущаяся, поверхностная. Элиот, как и другие модернисты, находится в поиске новых мифов, способных объединить разрозненный на части мир, преодолеть отчуждение человека от общества и природы. По утверждению А. Гениса, центральным проектом модернистов становится нахождение нового мифа, способного «одухотворить прогресс и срастить распавшийся мир в новое единство» [29]. Модернисты перенимают мысль предыдущей эпохи о важной роли поэта в жизни страны.

Внимание многих писателей-модернистов сосредоточивается на самих вещах, в которых они пытаются обнаружить новый смысл. Они стараются обеспечить «свежесть и резкость образного восприятия», поэтому «утверждают принцип постоянного насилия по отношению к языку, постоянной ломки и перекраивания языкового материала» [30. С. 263]. В 1912 г. возникает направление имажизма во главе с Эзрой Паундом (1885-1972) [31. С. 6], которого Генис называет «апостолом модернизма». Именно Паунд во многом определяет дальнейшее развитие американской поэзии [Там же. С. 5]. Он является автором не только многочисленных стихотворений, переводов, но и автором работ по литературоведению и культуре. Паунд способствует продвижению малоизвестных поэтов, являясь центром движения авангардистов в Лондоне, Париже и Нью-Йорке. Его творческие принципы остаются значимыми даже для современных поэтов [32. С. 50]. Во многом благодаря Паунду утверждается свободный стих, занявший ключевые позиции в американской поэзии новой эпохи. Одной из основных его идей, которая жива и по сей день, является утверждение необходимости отсечения от стихотворения лишних слов для избавления от излишней декоративности [28. С. 25]. Эта идея стала результатом увлечения восточной поэзией, переводами которой он занимался. Так, в 1913 г. появляется стихотворение Паунда «На станции метро» (In a Station of the Metro), напоминающее хайку:

The apparition of three faces in the crowd;

Petals on a wet, black bough [Ibid. P. 26].

Увлечение китайской и японской поэзией, как, впрочем, и духовными учениями Востока, стало отличительной чертой возникшей впоследствии группы битников. Хотя философия Востока, как было сказано ранее, стала проникать в литературу США ещё во времена Эмерсона и Торо, особый интерес она вызвала после Второй мировой войны в годы поиска новых духовных начал.

Говоря о развитии поэзии о природе, стоит отметить творчество Уильяма Карлоса Уильямса (18831963). Образ природы в его творчестве создаётся с помощью указания на мелкие детали. Примером служит стихотворение «Красная тачка» (The Red Wheelbarrow), в котором представлены три образа отдельных предметов, связанных воедино структурой стихотворения [33]. Несмотря на краткость стихотворения, оно может вызвать различные интерпретации, что говорит о силе создаваемых образов простых матери- альных объектов [28. С. 99]. Звуковая и ритмическая гармония передают доставляемое наслаждение представленным пейзажем. Цвета предметов можно воспринять как цвета американского флага, тогда идеей стихотворения может быть значимость фермерства для жизни страны. Образ природы, таким образом, связан с образом страны и отражает ценность простой жизни.

Основным отличием Уильямса от Элиота и Паунда является его убеждённость в необходимости внимания к своему месту проживания, своей малой родине [23. С. 376]. Космополитизму он противопоставляет локализм, считая, что национальное проявляется в локальном. Если поэзия Элиота и Паунда содержит большое количество аллюзий на произведения прошлого и настоящего, то поэзия Уильямса отличается простотой и представляет обычную жизнь его родного города. Образ природы в творчестве модернистов часто связан с образом города. Например, эти два образа связаны в стихотворении Э. Бишоп «Простое упражнение» (Little Exercise):

It is raining there. The boulevard

And its broken sidewalks with weeds in every crack

Are relieved to be wet, the sea to be freshened [35].

Локализм характерен для творчества ещё одного известного американского поэта - Роберта Фроста (1874-1963). ДиФранко отмечает, что стихотворения Фроста вносят вклад в создание национальной пасторали, а также помогают определить американскую идентичность через приверженность к конкретному месту проживания [3. С. 227]. Однако стоит отметить, что отношение Фроста к природе двойственно. Если в творчестве Уильямса образ природы однозначно положителен и несёт идею возможности обновления (заложенную, например, в сборнике «Весна и всё остальное» (Spring and All)), то образ природы у Фроста амбивалентен, что возвращает нас к идеям пуританизма. Амбивалентность можно проследить в произведениях «Остановка в лесу снежным вечером» (Stopping by Woods), «Войди» (Come In), в которых признание красоты природного соседствует с осознанием губительности полного погружения в природу (что также говорит о вере в невозможность слияния с природой). Нередко поэтому в поэзии Фроста образ природы связан с образами света и тьмы, дня и ночи. Например, в стихотворении «Знакомство с ночью» (Acquainted with the Night) он пишет:

And further still at an unearthly height,

One luminary clock against the sky

Proclaimed the time was neither wrong nor right

I have been one acquainted with the night [9. P. 230-231].

Природное начало в стихотворении ассоциируется с темнотой, а человеческая деятельность, символом которой являются часы, - со светом.

В известном произведении «Берёзы» (Birches) Фрост соединяет два видения природы, говоря о возможности сочетания духовной жизни с земными делами. Если сравнить это стихотворение со стихотворением «Берёза» Сергея Есенина, то можно понять, насколько различным является восприятие одного и того же дерева этих двух выдающихся поэтов. Если для Есенина берёза - это нечто близкое, ассоциирую- 
щееся с родиной, женским началом, вызывающее эстетическое восхищение, то для Фроста - это нечто, к чему можно обратиться лишь по необходимости для удовлетворения порывов души. Склонённые берёзы у Фроста тоже ассоциируются с женщинами, однако задача автора заключается не в передаче эстетической ценности природы. Основная идея стихотворения заключается в возможности использования природы как средства достижения наслаждения. Если подъём по берёзе ассоциируется с духовным ростом, приближением к небесам, то спуск с берёзы на землю подразумевает возврат к земной жизни, земным заботам. Понимание природы близко к пониманию её пуританами. Пространство у Фроста разделено на положительный «верх» и отрицательный «низ».

Форма произведений Фроста достаточно традиционна (например, в стихотворении «Берёзы» превалирует традиционный для классического английского стихосложения ямбический пентаметр), однако она содержит в себе и элементы новаторства (обращение к речевым особенностям своего родного региона) [23. С. 351]. Поэзия Фроста, таким образом, как и поэзия Мелвилла, является неким переходным явлением (по выражению А. Гениса, протомодернистским) [35].

К числу модернистов, чьё творчество отмечено особым вниманием к природному миру, можно отнести наряду с уже перечисленными выше следующих поэтов: Уоллеса Стивенса (1879-1955), убеждённого в возможности самопознания посредством обращения к окружающей среде, Марианну Мур (1887-1972), часто обращающуюся к образам животных (например, в стихах «Рыба» (The Fish), «Осьминог» (An Octopus)) и конкретным географическим местам, а также Элизабет Бишоп (1911-1979), отличающуюся вниманием к деталям природного мира.

Всех поэтов третьего периода развития поэзии о природе объединяет желание найти духовную основу для будущего существования человека, они все обеспокоены вопросом нахождения места человека в неустойчивом, изменяющемся мире. Зыбкость бытия в творчестве некоторых модернистов передаётся частым использованием образа стекла, зеркал, отражения в воде. Достаточно распространённым становится анжамбеман, использование которого, как правило, подчёркивает невозможность создания законченного образа, а также деавтоматизирует наше восприятие, выделяя наиболее значимые в смысловом отношении места. Его, например, использует Э. Бишоп в стихотворении «Простое упражнение» (Little Exercise):

Where occasionally a heron may undo his head,

Shake up his feathers, make an uncertain comment

When the surrounding water shines [34].

Практически все поэты данного периода подчёркивают субъективность восприятия природы с помощью большого количества сравнений. Например, достаточно много сравнений есть в стихотворении Бишоп «В рыбацких хижинах» (At the Fishhouses):

The lobster pots, and masts, scattered

Among the wild jagged rocks,

Is of an apparent translucence

Like the small old buildings with an emerald moss

Growing on their shoreward walls [36].
Сравнение можно найти в стихотворении Стивенса «Простой смысл» (The Plain Sense of Things), а также в стихотворении «Осьминог» (An Octopus) Марианны Мур. Как утверждает И.В. Кабанова, «модернисты превыше всего ставят ценность индивидуального художнического видения мира» [37]. Образ природы, таким образом, на третьем этапе подчинён задаче самовыражения личности поэта, считающего возможным с помощью своего творчества создать мир заново. А. Генис поясняет, что одной из главных задач модернизма было показать то, что фантастическое составляет неотъемлемую часть обычного посредством обращения к вещам, являющимися связующими звеньями между иррациональными и рациональными сферами бытия, а также посредниками между внутренней и внешней реальностью: «Между ними нет отличий, ибо и то и другое - продукт нашего сознания <..> Задача искусства вообще и поэта в частности состоит в том, чтобы соединить две части нашего опыта» [35]. Природа - это как раз то, что позволяет поэтам выявить связь между внутренней и внешней реальностью.

Наконец, четвёртым этапом развития поэзии о природе является современный период, начавшийся после Второй мировой войны. Если на первом этапе развития природный мир интересовал поэтов как творение Бога, на втором - как растворённое божественное начало, имеющее единую природу с человеческим началом, то на третьем - как средство самопознания. На четвёртом этапе природа интересует поэтов как наделённый внутренней ценностью мир, как система, объединяющая равнозначные элементы. Современных поэтов интересует динамика взаимодействия человека с другими элементами природной системы, а также нравственная составляющая этого взаимодействия. Уже ни у кого не вызывает сомнение взаимозависимость всего сущего. Вторая половина ХХ в. отмечена растущим пониманием поэтами той роли, которую человек играет в изменениях, происходящих в природном мире. Д.С. Лихачёв утверждал, что необходимо на основе философии экологии построить этику экологии, поскольку «отсутствие в природе духовного человека, представляющего как бы “самосознание вселенной”, лишает смысла существования не только человека, но и все сущее, все мироздание» [38. C. 98]. Литература неизменно транслирует ценности, поэтому она может помочь сформировать этику экологии. Творчество многих современных поэтов можно отнести к эколитературе, поскольку в их произведениях предметом изображения становятся взаимодействие человека со всей природной системой, а также нравственные вопросы этого взаимодействия

К данному нами ранее определению эколитературы как литературы, «в центре внимания которой находится взаимосвязь человека с другими сущностями естественной природы, включая реки и горы» [39. С. 12], можно добавить утверждение о том, что эколитература затрагивает вопросы этического характера взаимодействия человека с другими элементами экосистемы. В качестве художественных средств выражения идеи взаимосвязи всего сущего экопоэты часто используют ассонанс и аллитерацию, внутрен- 
нюю рифму и прочие средства, помогающие связать слова стихов в единую сеть.

К экопоэзии как одному из видов эколитературы можно отнести творчество Гэри Снайдера, Мэри Оливер, творчество таких представителей коренного населения, как Лесли Мармон Силко, Луис Элдрич, Линда Хоган, Шерман Алекси, Джой Харджо и некоторых других. Достаточно широкое освещение черты экопоэзии получили в работах американского исследователя Дж.С. Брайсона. Он выделяет следующие черты экопоэзии: экоцетристская перспектива, привязанность к конкретному месту на земле, представление мира как сообщества взаимосвязанных субъектов, осознание необходимости смирения человеческой гордыни, скептицизм по отношению к особого вида рациональности, присущей якобы человеку, и обеспокоенность возможностью экологической катастрофы [40. С. 143]. Образ природы в произведениях экопоэтов - это образ объединённых в единое целое взаимосвязанных существ.

В произведениях представителей коренного населения не только люди, животные и растения представлены как живые существа, но также различные объекты физического мира и душа: «For the soul is a wanderer with many hands and feet» [41]. По утверждению Е.А. Стеценко, автора многих трудов по американской литературе, «экологическая» литература XX в. развивает традиционный для национальной культуры мотив конфликта естественного бытия и цивилизации» [42. С. 19]. В произведениях представителей коренного населения США, как уже было отмечено ранее, часто звучит трагизм из-за нарушенных взаимоотношений человека с остальным природным миром. Примером таких произведений может служить стихотворение Шермана Алекси (р. 1966) «Пау-вау на краю света» (The Powwow at the End of the World) в котором он говорит, что прежний дух традиционного собрания индейцев пау-вау возможно восстановить, только если будут устранены последствия вмешательства европейцев в природный мир континента [43].

Хотя произведения Алекси написаны с юмором и являются скорее жизнеутверждающими, чем апокалиптическими, в них постоянно присутствует мотив «края», «конца мира»:

Damn, says Crow, I guess

They already live near the end of the world [44].

У Дж. Харджо (р. 1951) этот мотив тоже присутствует. Например, он есть в стихотворении «Возможно, мир закончится на этом» (Perhaps the World Ends Here). В стихотворении «Исчез мир, который мы знали» (When the World as We Knew It Ended) Дж. Харджо пишет:

And then it was over, this world we had grown to love

For its sweet grasses, for the many-colored horses

And fishes, for the shimmering possibilities

While dreaming [45].

Заметно, что стихотворения американских индейцев часто представляют собой сюжетные повествования. В них встречаются образы мифологических существ, несущие дополнительный смысл и, как правило, подчёркивающие взаимосвязь и взаимозависи- мость человека и других природных существ друг от друга. Это может быть ворон в таких стихотворениях Алекси, как «Завещание ворона» (Crow Testament) и «Эволюция» (Evolution), или белый олень в стихотворениях Харджо и т.д.

Элементы повествования можно найти и в произведениях таких современных поэтов, как Мэри Оливер и Гэри Снайдер. Среди работ Мэри Оливер (р. 1935) можно выделить такие книги, как «Без путешествий и другие стихи» (No Voyage, and Other Poems), «Река Стикс, Огайо и другие стихотворения» (The River Styx, Ohio, and Other Poems), «12 Лун» (Twelve Moons), «Американский примитив» (American Primitive) и др. Поэзия Оливер отличается обилием образов конкретных мест, в которых чувствуется внимание к деталям природного мира. Например, их можно найти в стихотворении «Сон в лесу» (Sleeping in the Forest).

Природа в поэзии Оливер является основным предметом изображения достаточно часто. Американский литературный критик А. Острайкер считает Оливер «одной из немногих американских поэтесс, способных передать восторг от общения с природой и в то же время сохранить понимание того, что в мире есть хищники и жертвы» [46]. Оливер старается передать идею ошибочности антропоцентризма, поскольку природа обладает ценностью сама по себе. Например, в стихотворении «Где начинается и заканчивается танец» (Where Does the Dance Begin, Where Does It End) Оливер использует метафору театра, главными актёрами в котором являются не люди, а природные явления. Люди также не являются театральными критиками:

Don't call this world adorable, or useful, that's not it.

It's frisky, and a theater for more than fair winds.

The eyelash of lightning is neither good nor evil.

The struck tree burns like a pillar of gold [47].

Оливер передаёт идею уникальности каждого дня, каждого природного явления, она представляет природу сущностью, в которой имманентно присутствует божественное начало, таким образом следуя традиции трансцендентализма. Подтверждением служат строки из стихотворения «Утреннее стихотворение» (Morning Poem):

Each pond with its blazing lilies

Is a prayer heard and answered

Lavishly,

Every morning [48].

В отличие от поэтов предыдущего периода Оливер, как и другие экопоэты, избегает сравнения природных явлений с качествами человека. В сборнике «Сила воображения» (Dream Work), например, Оливер для передачи связи между различными представителями природы использует метафору семьи, образ мира - это образ стаи диких гусей с их резким и призывным криком:

Whoever you are, no matter how lonely,

The world offers itself to your imagination,

Calls to you like the wild geese, harsh and exciting

Over and over announcing your place

In the family of things [Ibid.].

Говоря об употреблении метафоры семьи, необходимо упомянуть также творчество ещё одного экопоэта - Гэри Снайдера (р. 1930). В его произведениях, как 
и в произведениях Мэри Оливер и других экопоэтов, присутствует эта метафора. Например, в стихотворении «Молитва великой семье» (Prayer for the Great Family) Снайдер так представляет устройство мира:

Gratitude to Mother Earth, sailing through night and day $<\ldots>$

Gratitude to the Great Sky

$<\ldots>$

Grandfather Space.

The Mind is his Wife [49. C. 24-25].

Метафора семьи удачно передаёт взаимосвязь и взаимозависимость различных элементов природной системы. Она также ставит вопрос о нравственных взаимоотношениях внутри данной системы. Идея взаимосвязи поддерживается аллитерацией, анафорой, параллелизмами.

Помимо этого Снайдер часто сравнивает природу с самой жизнью, а жизнь - с работой («Рабочий день» (Work Day), «Настоящая работа» (The Real Work)). Образ природы в творчестве Снайдера в целом непосредственно связан с образом движения, процесса. В его стихотворениях природа - это также дом. Как правило, образ дома в стихотворениях Снайдера - это образ всего мира, вселенной. Подобный образ можно найти в стихотворении «Через отверстие для дыма» (Through the Smoke Hole), в котором реализуется представление индейцев о нескольких мирах, связанных между собой [50. С. 125].

Идея взаимосвязи элементов природной системы в творчестве Снайдера передаётся также за счёт образа рек и гор. Например, данный образ является центральным в стихотворении «Бескрайние горы и реки». П. Тоуви отмечает, что образ гор наряду с образом рек имеет у Снайдера схожее значение с тем, которое вкладывали в него поэты эпохи романтизма [51. C. 23]. В понимании Снайдера образ гор и рек представляет собой выражение взаимодействия универсума с душой человека, целостности, присущей миру: «...a big view of the whole phenomenal world continually arising, all of it seen as mountains and rivers, a nondual view» [52. Р. 77]. Таким образом, в творчестве экопоэтов различными путями утверждается идея взаимосвязи, а также множественности, многообразия, которое обогащает жизнь.

Итак, проследив процесс трансформации образа природы в литературе США, можно сделать заключение, что историю развития поэзии о природе можно условно поделить на следующие этапы:

1) от начала колонизации до эпохи романтизма;

2) эпоха романтизма - начало гражданской войны;

3) Гражданская война - эпоха модернизма;

4) современная эпоха.

На первом этапе главенствующую позицию в иерархии ценностей колонистов занимало служение богу. Образ природы в основном был призван выразить идею греховности человека. Художественное пространство имело резкое разделение на положительный «верх» и отрицательный «низ». Помимо использования природных образов из Библии авторы использовали приём олицетворения.

На втором этапе природа часто была представлена в образе одухотворённой сущности, имевшей единой начало с человеческой сущностью. В основе создания образа природы лежала одна из главных ценностей американской культуры - ценность человеческой личности. Образ природы в произведениях большинства поэтов, чьё творчество принадлежит ко второму периоду развития поэзии о природе, связан с образом страны.

На третьем этапе образ природы - это образ собранных воедино согласно субъективному восприятию поэта фрагментов. При создании образа природы авторы часто обращались к материальным объектам, их мелким деталям, которые поэт хотел преподнести как нечто новое, имеющее особый смысл. В эпоху модернизма поэты пытались найти основание для дальнейшего существования человека в мире, и для некоторых таким основанием стало укрепление связей с природой. Основной ценностью становится сама поэзия, мыслимая как способ построить новый мир.

На четвёртом этапе поэзия о природе превращается в экопоэзию. Поэты представляют природу как систему взаимосвязей, обладающую самоценностью. В центре внимания стоит разработка нравственных вопросов взаимодействия человека с другими членами природного сообщества.

Сегодня проявляется большой интерес к мифам и литературе коренных народов. Творчество, например, таких представителей коренного населения, как Джой Харджо, Шермана Алекси, занимает особое место в литературе США. Несмотря на то что поэзия стала более секулярна с течением времени, даже на современном этапе есть авторы, убеждённые в том, что природа - это божественная сущность. Мэри Оливер - одна из них. Новым явлением на современном этапе является пристальное внимание к деталям природного мира, к взаимосвязи его частей. Несмотря на то что некоторые поэты до сих пор используют образ природы как создания Бога, произошёл переход от теоцентристкой парадигмы к биоцентристской. Человек уже не представляется тем созданием, ради которого существует всё на земле. В произведениях экопоэтов виден сдвиг от признания ценности человеческой индивидуальности к признанию ценности каждого элемента экосистемы. В художественном плане это выражается:

1) в обращении к определённым метафорам (метафоре семьи, метафоре гор и рек, метафоре дома и проч.);

2) отказе от сравнения природных явлений с миром человека;

3) внимании к деталям природного мира, представленного в виде системы взаимосвязанных частей;

4) обращении к мифам, что, во-первых, обогащает произведения, связывая их с культурно-историческим прошлым человечества, с теми временами, когда человек ещё не выделял себя из природы, а, во-вторых, говорит о возможности альтернативного видения действительности;

5) приверженности к свободному стиху (происходит отказ от рифмы, определённого метра, ритма), что позволяет выразить идею того, что в мире нет раз и навсегда установленного порядка. 


\section{ЛИТЕРАТУРА}

1. Докучаев И.И. Ценность и экзистенция. Основоположения исторической аксиологии культуры. СПб. : Наука, 2009. 595 с.

2. Дымина Е.В. Мир ценностей и проблема осмысления действительности // Ценности и смыслы. 2009. № 2. С. $27-37$.

3. DiFranco A.K. Nature Writing: Poetry // Oxford Encyclopedia of American Literature. Oxford : Oxford University Press, 2004. Vol. 3. P. 219231.

4. Гиленсон Б.А. История литературы США : учеб. пособие для студентов высш. учеб. заведений. М. : Академия, 2003.704 с.

5. Fredman S. A Concise Companion to Twentieth-Century American Poetry. Oxford : Blackwell Publishing, 2005.288 p.

6. Грицман А. Живой пейзаж (четверть века американской поэзии) // Арион. Слово. 2001. №. 2. C. 17-28. URL: http://magazines.russ.ru/ arion/2001/2/gric.html (дата обращения: 04.06.2015).

7. Bradstreet A. Contemplations // Poetry Foundation. URL: http://www.poetryfoundation.org/poems-and-poets/poems/detail/43699 (accessed: 07.06.2016).

8. Bradstreet A. In Reference to Her Children // Fire and Ice: Puritan and Reformed Writings. URL: http://www.puritansermons.com/poetry/anne08.htm (accessed: 07.06.2016).

9. Lehman D. The Oxford Book of American Poetry. New York : Oxford University Press, 2006. 1200 p.

10. Freneau Ph. The Indian Burying Ground // Poetry Foundation. URL: http://www.poetryfoundation.org/poems-and-poets/poems/detail/46094 (accessed: 21.05.2016).

11. Dwight T. Greenfield Hill // Early Americas Digital Archive. URL: http://mith.umd.edu/eada/html/display.php?docs=dwight_greenfieldhill.xm (accessed: 08.06.2016).

12. Американская поэзия в русских переводах. XIX-XX вв. / сост. С.Б. Джимбинов. М. : Радуга, 1983.672 с.

13. Simms W.H. Flight to Nature // PoemHunter.com URL: http://www.poemhunter.com/poem/flight-to-nature/ (accessed: 22.06.2016).

14. Romanticism and Transcendentalism: 1800-1860 / ed. A. Ladd. New York : Infobase Publishing, 2010.126 p.

15. Emerson R.W. Emerson: Selected Essays / ed. L. Ziff London: Penguin, 1982. 416 p.

16. Павлычко С.Д. Философская поэзия американского романтизма (поэтическое творчество Ралфа Уолдо Эмерсона и Эмили Дикинсон) : дис. ... канд. филол. наук. Киев, 1984. 188 с.

17. Богословский В.Н., Прозоров В.Г., Головченко А.Ф. Американская литература: Романтизм. URL: http://www.ae-lib.org.ua/texts/bogoslovskiy american romantism ru.htm (дата обращения: 09.06.2016).

18. Gray R.A History of American Literature. Oxford : Blackwell Publishers Ltd., 2004. 913 p.

19. VanSpanckeren K. Outline of American Literature. Washington: U. S. Department of State, 2006. 177 p. URL: http://iipdigital.usembassy.gov/st/ english/publication/2011/07/20110727110855su0.6739575.html\#axzz3Kkjyls1t (accessed: 12.06.2016).

20. Maunder A. Encyclopedia of Literary Romanticism. New York : Facts on File, 2010. 560 p.

21. Tappan C.S. Lyric // The Web of American Transcendentalism. URL: http://transcendentalism-legacy.tamu.edu/ (accessed: 09.07.2016).

22. Эстетика американского романтизма / сост. А.Н. Николюкин. М. : Искусство, 1977. 464 с.

23. Gray R.A. History of American Literature. $2^{\text {nd }}$ ed. Oxford : Wiley-Blackwell, 2012.913 p.

24. Dickinson E. I'm Nobody! Who are you? // Academy of American Poets. URL: https://www.poets.org/poetsorg/poem/im-nobody-who-are-you260 (accessed: 19.06.2016).

25. Dickinson E. "Nature" Is What We See // PoemHunter.com. URL: http://www.poemhunter.com/poem/nature-is-what-we-see (accessed: 19.06.2016).

26. Felstiner J. Can Poetry Save the Earth? A Field Guide to Nature Poems. New Haven : Yale University Press, 2009.396 p.

27. Longfellow H.W. Nature // Poetry Foundation. URL: http://www.poetryfoundation.org/poems-and-poets/poems/detail/44641 (accessed: 21.06.2016).

28. Beach Ch. The Cambridge Introduction to Twentieth-Century American Poetry. Cambridge : Cambridge University Press, 2003.234 p.

29. Генис А. Модернизм как стиль XX века. URL: http://magazines.russ.ru/zvezda/2000/11/genis.html (дата обращения: 12.06.2016).

30. Гаспаров Б.М. Язык. Память. Образ. Лингвистика языкового существования. М. : Новое литературное обозрение, 1996.352 с.

31. Beasley R. Theorists of Modernist Poetry: T.S. Eliot, T.E. Hulme, Ezra Pound. London : Routledge, 2007.160 p.

32. MacGowan Ch. Twentieth-Century American Poetry. Hoboken : Wiley-Blackwell, 2004. 348 p.

33. Williams W.C. The Red Wheelbarrow. URL: http://www.poetryfoundation.org/resources/learning/core-poems/detail/45502 (accessed: 08.07.2016).

34. Bishop E. Little Exercise // PoemHunter.com. URL: http://www.poemhunter.com/poem/little-exercise/ (accessed: 08.07.2016).

35. Генис А., Гандельсман В. Двойной портрет американских поэтов // Радио Свобода. URL: http://www.svoboda.org/content/ transcript/1791996.html (дата обращения: 18.06.2016).

36. Bishop E. At the Fishhouses // Poetry Foundation. URL: http://www.poetryfoundation.org/poems-and-poets/poems/detail/52192 (accessed: 11.07.2016).

37. Кабанова И.В. Зарубежная литература. Учебное пособие. URL: http://17v-euro-lit.niv.ru/17v-euro-lit/kabanova/modernizm.htm (дата oбpaщения: 18.06.2016).

38. Лихачёв Д.С. Русская культура. М. : Искусство, 2000. 440 с.

39. Гречишкина С.В. К вопросу исследования современной литературы о природе: аспекты изучения эколитературы // Вестник Томского государственного университета. 2014. № 387. С. 8-14.

40. Bryson J.S. Seeing the West Side of Any Mountain. Thoreau and Contemporary Ecological Poetry // Thoreau's Sense of Place. Essays in American Environmental Writing / ed. R.J. Schneider. Iowa City : University of Iowa Press, 2000. P. 133-145.

41. Harjo J. A Map to the Next World // Poetry Foundation. http://www.poetryfoundation.org/poems-and-poets/poems/detail/49621 (accessed: 11.07.2016).

42. Стеценко Е.А. Литература США начала ХХ века // История литературы США : в 5 т. / ред. Я.Н. Засурский. М. : ИМЛИ РАН, 2009. Т. 5. C. $10-29$.

43. Alexie Sh. The Powwow at the End of the World // Poetry Foundation. URL: http://www.poetryfoundation.org/poems-and-poets/poems/detail/47895 (accessed: 11.07.2016).

44. Alexie Sh. Crow Testament// Genius. URL: http://genius.com/Sherman-alexie-crow-testament-annotated (accessed: 11.07.2016).

45. Harjo J. When the World as We Knew It Ended. URL: http://www.poetryfoundation.org/poems-and-poets/poems/detail/49619 (accessed: 14.07.2016).

46. Ostriker A. Mary Oliver. URL: http://peacefulrivers.homestead.com/maryoliver.html (accessed: 19.06.2016).

47. Oliver M. Where Does the Dance Begin, Where Does It End // Poetry Foundation. URL: http://www.poetryfoundation.org/poems-andpoets/poets/detail/mary-oliver (accessed: 19.06.2016).

48. Poetry by Mary Oliver. URL: http://peacefulrivers.homestead.com/MaryOliver.html (accessed: 19.06.2016).

49. Snyder G. Turtle Island. New York : New Directions Publishing Corporation, 1974. 114 p.

50. Snyder G. The Back Country. New York : New Directions Publishing Corporation, 1971. $151 \mathrm{p}$.

51. Tovey P. The Transatlantic Eco-Romanticism of Gary Snyder. London : Palgrave Macmillan, 2013. 260 p.

52. Snyder G., Martin J. Nobody Home: Writing, Buddhism, and Living in Places. San Antonio : Trinity University Press, 2014. 268 p.

Статья представлена научной редакцией «Филология» 8 мая 2017 г. 
THE DEVELOPMENT OF NATURE POETRY IN THE USA: THE EMERGENCE OF ECOPOETRY

Vestnik Tomskogo gosudarstvennogo universiteta - Tomsk State University Journal, 2017, 419, 32-44. DOI: $10.17223 / 15617793 / 419 / 4$

Svetlana V. Grechishkina, Transbaikal State University (Chita, Russian Federation). E-mail: Sveta-only4me@mail.ru

Keywords: American poetry; nature poetry; image of nature; ecoliterature; ecopoetry; values.

The article focuses on American nature poetry, ecopoetry in particular. The topicality of the article results from the increasing interest to the literary works about nature. The study of nature poetry supplements the research of the system "human-nature", the results of which are necessary for finding sustainable ways of existence of a human as an integral part of nature. Finding such ways as well as regulating the moral attitude of humans towards nature is a present-day priority. The aim of this research is to detect the transformation of the image of nature in every period of development of American nature poetry and identify the characteristic features of ecopoetry. One of the primary objectives is to find out how cultural and historical circumstances influenced the changes in the image of nature. The primary methods of the research are cultural-historical and comparative methods. The main approach is axiological. This approach allows to find out what values were at the heart of the image creation. The author of the article assumes that the distinctive features of the image of nature depend upon the values of an author's value system and values typical to a certain historical period. The novelty of the research results partly from touching upon such a phenomenon as ecopoetry which appeared on the last stage of nature poetry development and which is a new field of interest for Russian literary studies and at the same time from the approach to the study of nature poetry. The author of the article analyses the works of such poets as A. Bradstreet, Ph. Freneau, T. Dwight, W. C. Bryant, R. W. Emerson, E. Dickinson, H. D. Thoreau, W. Whitman, H. W. Longfellow, H. Melville, T. S. Eliot, W. C. Williams, R. Frost, E. Bishop, M. Oliver, G. Snyder, Sh. Alexie and J. Harjo. The process of American nature poetry development can be divided into the following periods: 1) from the start of European colonization of America till Romanticism, 2) from Romanticism till the beginning of the American Civil War, 3) from the beginning of the American Civil War till Modernism, 4) present day. The primary value in the colonists value hierarchy was serving God. The image of nature reflected the idea of sinfulness of man. Literary space was divided into the positive 'upper part' and the negative 'lower part'. The poets used Biblical images as well as personification. The second period of nature poetry development saw nature as a spiritual phenomenon having a common origin with the human spirit. The creation of the image of nature was based on one of the main values of American culture - the value of personality. Nature was seen as a source of satisfaction of various human needs. In the third period poets paid close attention to the minor details of material objects and to the place where they lived. The aim of the poets was to make the readers see their surroundings afresh. For some poets to make the relations to nature stronger became one of the bases for the further human existence. In the fourth period nature poetry turned into ecopoetry. Ecopoetry focuses on the ethical questions of the relationship of man with other members of natural community and on the intrinsic value of each element of the ecosystem. It results in using special metaphors (the metaphor of family, home, etc.), rejecting the comparison of natural phenomena with the qualities of man, paying attention to the details of nature, turning to myths and using free verse.

\section{REFERENCES}

1. Dokuchaev, I.I. (2009) Tsennost' i ekzistentsiya. Osnovopolozheniya istoricheskoy aksiologii kul'tury [Value and existence. Fundamentals of historical axiology of culture]. St. Petersburg: Nauka.

2. Dymina, E.V. (2009) Mir tsennostey i problema osmysleniya deystvitel'nosti [The world of values and the problem of understanding the reality]. Tsennosti i smysly. 2. pp. 27-37.

3. DiFranco, A.K. (2004) Nature Writing: Poetry. In: Oxford Encyclopedia of American Literature. Vol. 3. Oxford: Oxford University Press.

4. Gilenson, B.A. (2003) Istoriya literatury SshA [History of US literature]. Moscow: Akademiya.

5. Fredman, S. (2005) A Concise Companion to Twentieth-Century American Poetry. Oxford: Blackwell Publishing.

6. Gritsman, A. (2001) Zhivoy peyzazh (chetvert' veka amerikanskoy poezii) [Live landscape (a quarter century of American poetry)]. Arion. Slovo. 2. pp. 17-28. [Online] Available from: http://magazines.russ.ru/ arion/2001/2/gric.html. (Accessed: 04.06.2015).

7. Bradstreet, A. (1981) Contemplations. [Online] Available from: http://www.poetryfoundation.org/poems-and-poets/poems/detail/43699. (Accessed: 07.06.2016).

8. Bradstreet, A. (1981) In Reference to Her Children. [Online] Available from: https://www.poetryfoundation.org/poems-andpoets/poems/detail/43704. (Accessed: 07.06.2016).

9. Lehman, D. (2006) The Oxford Book of American Poetry. New York: Oxford University Press.

10. Freneau, Ph. (2006) The Indian Burying Ground. [Online] Available from: http://www.poetryfoundation.org/poems-andpoets/poems/detail/46094. (Accessed: 21.05.2016).

11. Dwight, T. (1794) Greenfield Hill. [Online] Available from: http://eada.lib.umd.edu/text-entries/greenfield-hill-a-poem/. (Accessed: 08.06.2016).

12. Dzhimbinov, S.B. (1983) Amerikanskaya poeziya v russkikh perevodakh. XIX-XXvv. [American poetry in Russian translations. 19th-20th centuries]. Moscow: Raduga.

13. Simms, W.H. (n.d.) Flight to Nature. [Online] Available from: http://www.poemhunter.com/poem/flight-to-nature/. (Accessed: 22.06.2016).

14. Ladd, A. (ed.) (2010) Romanticism and Transcendentalism: 1800-1860. New York: Infobase Publishing.

15. Emerson, R.W. (1982) Emerson: Selected Essays. London: Penguin.

16. Pavlychko, S.D. (1984) Filosofskaya poeziya amerikanskogo romantizma (poeticheskoe tvorchestvo Ralfa Uoldo Emersona i Emili Dikinson) [Philosophical poetry of American romanticism (the poetic work of Ralph Waldo Emerson and Emily Dickinson)]. Philology Cand. Diss. Kiev.

17. Bogoslovskiy, V.N., Prozorov, V.G. \& Golovchenko, A.F. (1991) Amerikanskaya literatura: Romantizm [American Literature: Romanticism]. [Online] Available from: http://www.ae-lib.org.ua/texts/bogoslov-skiy_american_romantism_ru.htm. (Accessed: 09.06.2016).

18. Gray, R. (2004) A History of American Literature. Oxford: Blackwell Publishers L $\overline{t d}$.

19. VanSpanckeren, K. (2006) Outline of American Literature. Washington: U.S. Department of State. [Online] Available from: http://iipdigital.usembassy.gov/st/ english/publication/2011/07/20110727110855su0.6739575.html\#axzz3 Kkjyls1t. (Accessed: 12.06.2016).

20. Maunder, A. (2010) Encyclopedia of Literary Romanticism. New York: Facts on File.

21. Tappan, C.S. (n.d.) Lyric. [Online] Available from: http://transcendentalism-legacy.tamu.edu/. (Accessed: 09.07.2016).

22. Nikolyukin, A.N. (1977) Estetika amerikanskogo romantizma [Aesthetics of American Romanticism]. Moscow: Iskusstvo.

23. Gray, R.A. (2012) History of American Literature. 2nd ed. Oxford: Wiley-Blackwell.

24. Dickinson, E. (1998) I'm Nobody! Who are you? [Online] Available from: https://www.poets.org/poetsorg/poem/im-nobody-who-are-you-260. (Accessed: 19.06.2016).

25. Dickinson, E. (2003) "Nature” Is What We See. [Online] Available from: http://www.poemhunter.com/poem/nature-is-what-we-see. (Accessed: 19.06.2016). 
26. Felstiner, J. (2009) Can Poetry Save the Earth? A Field Guide to Nature Poems. New Haven: Yale University Press.

27. Longfellow, H.W. (n.d.) Nature. [Online] Available from: http://www.poetryfoundation.org/poems-and-poets/poems/detail/44641. (Accessed: 21.06.2016).

28. Beach, Ch. (2003) The Cambridge Introduction to Twentieth-Century American Poetry. Cambridge: Cambridge University Press.

29. Genis, A. (2000) Modernizm kak stil' $X X$ veka [Modernism as a style of the 20th century]. [Online] Available from: http://magazines.russ.ru/zvezda/2000/11/genis.html. (Accessed: 12.06.2016).

30. Gasparov, B.M. (1996) Yazyk. Pamyat’. Obraz. Lingvistika yazykovogo sushchestvovaniya [Language. Memory. Image. Linguistics of language existence]. Moscow: Novoe literaturnoe obozrenie.

31. Beasley, R. (2007) Theorists of Modernist Poetry: T.S. Eliot, T.E. Hulme, Ezra Pound. London: Routledge.

32. MacGowan, Ch. (2004) Twentieth-Century American Poetry. Hoboken: Wiley-Blackwell.

33. Williams, W.C. (1938) The Red Wheelbarrow. [Online] Available from: http://www.poetryfoundation.org/resources/learning/corepoems/detail/45502. (Accessed: 08.07.2016).

34. Bishop, E. (2003) Little Exercise. [Online] Available from: http://www.poemhunter.com/poem/little-exercise/. (Accessed: 08.07.2016).

35. Genis, A. \& Gandel'sman, V. (1996) Dvoynoy portret amerikanskikh poetov [A double portrait of American poets]. [Online] Available from: http://www.svoboda.org/content/ transcript/1791996.html. (Accessed: 18.06.2016).

36. Bishop, E. (1983) At the Fishhouses. [Online] Available from: http://www.poetryfoundation.org/poems-and-poets/poems/detail/52192. (Accessed: 11.07.2016).

37. Kabanova, I.V. (n.d.) Zarubezhnaya literatura [Foreign literature]. [Online] Available from: http://17v-euro-lit.niv.ru/17v-eurolit/kabanova/modernizm.htm. (Accessed: 18.06.2016).

38. Likhachev, D.S. (2000) Russkaya kul'tura [Russian culture]. Moscow: Iskusstvo.

39. Grechishkina, S.V. (2014) On contemporary nature literature studies: the aspects of ecological literature research. Vestnik Tomskogo gosudarstvennogo universiteta - Tomsk State University Journal. 387. pp. 8-14. (In Russian). DOI: 10.17223/15617793/387/2

40. Bryson, J.S. (2000) Seeing the West Side of Any Mountain. Thoreau and Contemporary Ecological Poetry. In: Schneider, R.J. (ed.) Thoreau's Sense of Place. Essays in American Environmental Writing. Iowa City: University of Iowa Press.

41. Harjo, J. (2002) A Map to the Next World. http://www.poetryfoundation.org/poems-and-poets/poems/detail/49621. (Accessed: 11.07.2016).

42. Stetsenko, E.A. (2009) Literatura SShA nachala XX veka [Literature of the USA of the beginning of the 20th century]. In: Zasurskiy, Ya.N. (ed.) Istoriya literatury SShA: $v 5$ t. [History of the literature of the USA: in 5 vols]. Vol. 5. Moscow: IWL RAS.

43. Alexie, Sh. (1996) The Powwow at the End of the World. [Online] Available from: http://www.poetryfoundation.org/poems-andpoets/poems/detail/47895. (Accessed: 11.07.2016).

44. Alexie, Sh. (n.d.) Crow Testament. [Online] Available from: http://genius.com/Sherman-alexie-crow-testament-annotated. (Accessed: 11.07.2016).

45. Harjo, J. (2002) When the World as We Knew It Ended. [Online] Available from: http://www.poetryfoundation.org/poems-andpoets/poems/detail/49619. (Accessed: 14.07.2016).

46. Ostriker, A. (2010) Mary Oliver. [Online] Available from: http://peacefulrivers.homestead.com/maryoliver.html. (Accessed: 19.06.2016).

47. Oliver, M. (2004) Where Does the Dance Begin, Where Does It End. [Online] Available from: http://www.poetryfoundation.org/poems-andpoets/poets/detail/mary-oliver. (Accessed: 19.06.2016).

48. Oliver, M. (2004) Poetry. [Online] Available from: http://peacefulrivers.homestead.com/MaryOliver.html. (Accessed: 19.06.2016).

49. Snyder, G. (1974) Turtle Island. New York: New Directions Publishing Corporation.

50. Snyder, G. (1971) The Back Country. New York: New Directions Publishing Corporation.

51. Tovey, P. (2013) The Transatlantic Eco-Romanticism of Gary Snyder. London: Palgrave Macmillan.

52. Snyder, G. \& Martin, J. (2014) Nobody Home: Writing, Buddhism, and Living in Places. San Antonio: Trinity University Press.

Received: 08 May 2017 